University of Nebraska - Lincoln

DigitalCommons@University of Nebraska - Lincoln

Faculty Papers and Publications in Animal

Science

Animal Science Department

1960

\title{
Carcass Characteristics of Swine as Influenced by Levels of Protein Fed in Pasture and in Dry Lot
}

\author{
D. B. Hudman \\ Nebraska Agricultural Experiment Station \\ E. R. Peo, Jr. \\ University of Nebraska-Lincoln
}

Follow this and additional works at: https://digitalcommons.unl.edu/animalscifacpub

Part of the Animal Sciences Commons

Hudman, D. B. and Peo, Jr., E. R., "Carcass Characteristics of Swine as Influenced by Levels of Protein Fed in Pasture and in Dry Lot" (1960). Faculty Papers and Publications in Animal Science. 622.

https://digitalcommons.unl.edu/animalscifacpub/622

This Article is brought to you for free and open access by the Animal Science Department at DigitalCommons@University of Nebraska - Lincoln. It has been accepted for inclusion in Faculty Papers and Publications in Animal Science by an authorized administrator of DigitalCommons@University of Nebraska - Lincoln. 


\title{
CARCASS CHARACTERISTICS OF SWINE AS INFLUENCED BY LEVELS OF PROTEIN FED ON PASTLRE ANI IN DRY LOT ${ }^{1}$
}

\author{
D. B. Hudman and E. R. Peo, JR. \\ Nebraska Agricultural Experiment Station, Lincoln"
}

\begin{abstract}
S EVERAL experiments have been conducted to compare the performance $\mathcal{S}$ of growing-finishing swine fed on pasture and in dry lot. Most of the early experimental research was conducted with rations that were lacking in vitamin and antibiotic supplementation. In these experiments the pigs fed on pasture tended to gain faster and more efficiently than those fed in dry lot. However, more recent research conducted by Hutchinson et al. (1955, 1956), Conrad and Beeson (1957) and Barnhart, Overfield and Lowry (1959) indicates that with supplemental vitamins and antibiotics, pigs fed in dry lot gained slightly faster than pigs fed on pasture.

Terrill (1954) indicated that the amount of protein needed for growingfinishing swine fed on good quality pasture was $2 \%$ less than for those fed in dry lot.

The experiment reported herein was conducted to compare the effect of well fortified corn-soybean oil meal rations containing $12 \%$ and $14 \%$ protein on carcass characteristics of swine fed on pasture or in dry lot.
\end{abstract}

\section{Experimental Procedure}

One hundred-sixty purebred Yorkshire, Hampshire, Duroc and crossbred Yorkshire-Hampshire pigs were randomly allotted by weight outcome groups and breeding to five replications of four experimental treatments of eight pigs per pen. 'This experiment was designed as a $2 \times 2$ factorial with two rations calculated to contain $12 \%$ and $14 \%$ protein fed to growing-finishing pigs on pasture or in dry lot.

The pigs fed on pasture were confined to a pen of approximately 0.5 acre of good alfalfa pasture. $\Lambda$ portable wooden house, $8^{\prime} \times 12^{\prime}$, with a wooden floor was used for shelter and shade in each pen. The dry lot pigs were housed in a brick building with an opening to a concrete apron on the outside of the building. These pens were cleaned daily. Both groups of pigs were provided with automatic waterers and self-feeders. All pigs and feeders were weighed at two-week intervals. The feed conversion (feed per pound of gain) and average daily gain were calculated for 70 days

\footnotetext{
' Published with the approval of the Director as Paper No. 1021, Journal Series, Nebraska Agricultural Experiment Station.

2 Department of Animal Husbandry. Acknowledgement is made to A. Markussen and associates for their assistance in caring for the experimental animals and to Chas. Pfizer and Co., Inc., Terre laute, Indiana; Merck and Co., Inc., Rahway, New Jersey; and American Cyanamid Co., Farm and Home Division, New York, New York. Acknowledgement is made to Geo. A. Hormel and Co., Fremont, Nebraska for their assistance in the collection of the carcass data.
} 
(June 19 through August 28). The lighter pigs were continued on their respective rations until they reached market weight.

Ten crossbred barrows were selected at random from each experimental treatment for slaughter. The gilts from this experiment were kept as breeding stock. The dressing percentage, carcass length, carcass weight and backfat thickness were obtained from the carcasses. Average backfat thickness was calculated as an average of three measurements (first rib, seventh rib and last lumbar vertebrate). An estimate of the percentage of fat and lean in the carcass was calculated from a core sample taken from the carcass immediately posterior to the last rib, one inch laterally and parallel to the split surface of the carcass as described by Lu $e t$ al. (1958).

The composition of the experimental rations are presented in table 1.

TABLE I. PERCENTAGE COMPOSITION OF EXPERIMENTAL RATIONS

\begin{tabular}{|c|c|c|}
\hline Ingredient & $12 \%$ protein ration & $14 \%$ protein ration \\
\hline Ground yellow corn & 86.1 & 80.9 \\
\hline $44 \%$ solvent soybean oil meal & 7.0 & 12.2 \\
\hline $50 \%$ meat and bone scraps & 2.5 & 2.5 \\
\hline $17 \%$ dehydrated alfalfa meal & 2.5 & 2.5 \\
\hline Ground limestone & 0.6 & 0.6 \\
\hline Steamed bone meal & 0.2 & 0.2 \\
\hline Salt (iodized) & 0.5 & 0.5 \\
\hline Trace minerals (high zinc, swine) & 0.1 & 0.1 \\
\hline Vitamin-antibiotic premix ${ }^{8}$ & 0.5 & 0.5 \\
\hline
\end{tabular}

a Contributed the following amounts of vitamins and antibiotics per lb. of complete ration: vitamin $\mathrm{D}_{2}$, 90 I.U.; riboflavin, $1.0 \mathrm{mg}$; niacin, $4.5 \mathrm{mg}$; calcium pantothenate, $2.0 \mathrm{mg}$; choline chloride, $105 \mathrm{mg}$; vitamin $\mathrm{B}_{12}, 5.0 \mathrm{mcg}$; and antibiotics, $5 \mathrm{mg}$.

\section{Results and Discussion}

A summary of the average daily gain and feed required per pound of gain is presented in table 2 . All statements concerning statistical significance are made at a probability of 0.05 or less (Snedecor, 1956). The pigs fed a $14 \%$ protein ration in dry lot made a significantly greater average daily gain than the pigs fed on pasture, but not significantly greater than the pigs fed the $12 \%$ protein ration in dry lot. The average daily gain of both groups of pigs fed in dry lot $(12 \%$ and $14 \%$ protein) was significantly greater than that of the pigs fed the $12 \%$ protein ration on pasture. Also, the average daily gain of the pigs fed in dry lot was significantly greater than the average daily gain (1.60 vs. 1.45 ) of those fed on pasture. The average feed required per pound of gain for pigs fed on pasture was significantly less than for the pigs fed in dry lot (3.04 vs. 3.29). There was no significant difference in the amount of feed required per pound of gain between protein levels within management systems. Lower average final weights and the consumption of alfalfa pasture may have contributed to the reduction in feed required per pound of gain for pigs fed on pasture. 
The average daily gain and feed required per pound of gain for different protein levels across management systems were not significantly different. Also, there was no significant interaction between protein level and system of management indicating that pigs of this weight and age gained at a comparable rate and feed efficiency regardless of protein level within management systems. Therefore, with these well-fortified rations there was no evidence that pasture-fed pigs required a lower percentage of protein in their ration than dry lot fed pigs.

TABLE 2. RESPONSE OF GROWING-FINISHING SWINE FED 12 AND 14 PERCENT PROTEIN RATIONS ON PASTURE AND IN DRY LOT

\begin{tabular}{|c|c|c|c|c|c|}
\hline \multirow[b]{2}{*}{ Treatment } & \multicolumn{2}{|c|}{ Dry lot } & \multicolumn{2}{|c|}{ Pasture } & \multirow[b]{2}{*}{$\mathrm{QSX}^{\mathrm{a}}$} \\
\hline & $\begin{array}{l}12 \% \\
\text { Protein }\end{array}$ & $\begin{array}{l}14 \% \\
\text { Protein }\end{array}$ & $\begin{array}{l}12 \% \\
\text { Protein }\end{array}$ & $\begin{array}{l}14 \% \\
\text { Protein }\end{array}$ & \\
\hline Pens per treatment, no. & 5 & 5 & 5 & 5 & \\
\hline Pigs per pen, no. & $8^{b}$ & 8 & 8 & $8^{b}$ & \\
\hline Av. initial wt., lb. & 64.1 & 64.2 & 64.2 & 64.4 & \\
\hline Av. final wt., lb. & 173.6 & 177.4 & 163.8 & 166.4 & \\
\hline Av. daily gain, lb. & 1.58 & 1.62 & 1.42 & 1.48 & 0.14 \\
\hline Feed per lb. gain, lb. & 3.33 & 3.24 & 3.02 & 3.05 & 0.24 \\
\hline Treatment & Dry lot & Pasture & $\begin{array}{l}12 \% \\
\text { Protein }\end{array}$ & $\begin{array}{c}14 \% \\
\text { Protein }\end{array}$ & \\
\hline $\begin{array}{l}\text { Pens per treatment, no. } \\
\text { Pigs per pen, no. }\end{array}$ & $\begin{array}{c}10 \\
8^{b}\end{array}$ & $\begin{array}{c}10 \\
8^{b}\end{array}$ & $\begin{array}{c}10 \\
8^{b}\end{array}$ & $\begin{array}{c}10 \\
8^{b}\end{array}$ & \\
\hline Av. initial wt., lb. & 64.2 & 64.3 & 64.2 & 64.3 & \\
\hline Av. final wt., $1 \mathrm{~b}$. & 175.5 & 165.1 & 168.6 & 171.9 & \\
\hline Av. daily gain, lb. & $1.60^{\circ}$ & $1.45^{\mathrm{c}}$ & 1.50 & 1.55 & \\
\hline Feed per lb. gain, lb. & $3.29^{\circ}$ & $3.04^{\mathrm{c}}$ & 3.18 & 3.15 & \\
\hline
\end{tabular}

it Difference required between treatment means for significance at $P=0.05$ or less

b One pig was removed from one pen.

- Difference between means significant at $P=0.05$ or less.

The carcass data are summarized in table 3 . The average final slaughter weight per treatment varied from 194.4 to $199.9 \mathrm{Ib}$. and the average cold carcass weight per treatment varied from 134.4 to $142.9 \mathrm{lb}$. The pigs fed in dry lot had a higher dressing percentage than the pigs fed on pasture $(71.68 \%$ vs. $69.83 \%)$ and those fed the $14 \%$ protein ration had a slightly higher dressing percentage than those fed the $12 \%$ protein ration $(71.25$ vs. 70.26). These differences were not statistically significant, nor was the difference in average carcass length between experimental treatments.

Pigs fed the $12 \%$ protein ration on pasture produced the thinnest backfat and the highest average estimated percentage of lean but differences were not significant. There was very little difference in backfat thickness and average estimated percentage of fat and lean between the protein levels. This finding is in agreement with the results of Crampton and 
TABLE 3. COMPARISON OF CARCASSES OF GROWING-FINISHING SWINE FED 1? AND 14 PERCENT PROTEIN RATIONS ON PASTURE AND IN DRY LOT

\begin{tabular}{|c|c|c|c|c|}
\hline \multirow[b]{2}{*}{ Treatment } & \multicolumn{2}{|c|}{ Dry lot } & \multicolumn{2}{|c|}{ Pasture } \\
\hline & $\begin{array}{c}12 \% \\
\text { Protein }\end{array}$ & $\begin{array}{c}14 \% \\
\text { Protein }\end{array}$ & $\begin{array}{l}12 \% \\
\text { Protein }\end{array}$ & $\begin{array}{l}14 \% \\
\text { Protein }\end{array}$ \\
\hline Barrows per treatment, no. & 10 & 10 & 10 & 10 \\
\hline Av, slaughter weight, $\mathrm{lb}$. & 198.8 & 199.9 & 194.4 & 199.0 \\
\hline Av, carcass wt., lb. & 140.7 & 145.1 & 135.6 & 139.1 \\
\hline Av. dressing \% & 70.8 & 72.6 & 69.8 & 69.9 \\
\hline Av. carcass length, in. & 29.4 & 29.3 & 29.3 & 29.3 \\
\hline Av. backfat thickness, in. & 1.70 & 1.72 & 1.60 & 1.69 \\
\hline Av. estimated fat, $\%^{a}$ & 45.82 & 45.47 & 44.72 & 45.14 \\
\hline Av. estimated lean, $\%^{a}$ & 39.60 & 39.87 & 40.72 & 40.13 \\
\hline Treatment & Dry lot & Pasture & $\begin{array}{l}12 \% \\
\text { Protein }\end{array}$ & $\begin{array}{l}14 \% \\
\text { Protein }\end{array}$ \\
\hline Barrows per treatment, no. & 20 & 20 & 20 & 20 \\
\hline Av. slaughter weight, lb. & 199.4 & 196.7 & 196.6 & 199.4 \\
\hline Av. carcass wt., lb. & 142.9 & 137.4 & 138.2 & 142.1 \\
\hline Av. dressing $\%$ & 71.7 & 69.9 & 703 & 71.2 \\
\hline Av. carcass length, in. & 29.4 & 29.3 & 29.3 & 29.3 \\
\hline Av. backfat thickness, in. & 1.71 & 1.64 & 1.65 & 1.70 \\
\hline Av. estimated fat, $\%^{a}$ & 45.64 & 44.76 & 45.10 & 45.30 \\
\hline Av. estimated lean, $\%^{a}$ & 39.74 & 40.42 & 40.16 & 40.00 \\
\hline
\end{tabular}

a According to Lu et al. (1958).

Ashton (1946) and Ashton et al. (1955) who reported no significant difference in carcass quality of pigs consuming rations that varied only $2 \%$ in protein content. The pigs fed in dry lot seemed to be slightly fatter than the pasture-fed pigs as evidenced by a thicker backfat and a higher percentage of estimated fat in the carcass. These observations are in agreement with those of Whatley et al. (1959); however, they reported that a corresponding difference was not observed when the carcass backfat was measured on a sample of the pigs.

\section{Summary}

One hundred and sixty growing-finishing pigs were fed $12 \%$ and $14 \%$ protein rations on pasture and in dry lot. The pigs fed in dry lot made significantly greater gains and required significantly more feed per pound of gain than the pigs fed on pasture.

The level of protein did not significantly affect the average daily gain or feed conversion. The protein level $\mathrm{x}$ management system (pasture and dry lot) interaction was not statistically significant for rate of gain and feed conversion.

Ten barrows were randomly selected from each of the four experimental 
treatments and slaughtered. Those fed on pasture had a slightly thinner backfat and less estimated carcass fat than those fed in dry lot. However, these differences were not statistically significant.

Level of protein did not significantly affect dressing percentage, carcass length, backfat thickness or estimated carcass lean or fat.

\section{Literature Cited}

Ashton, G. C., J. Kastelic, D. C. Acker, A. H. Jensen, H. M. Maddock, E. A. Kline and D. V. Catron. 1955. Different protein levels with and without antibiotics for growing-finishing swine: Effect on carcass leanness. J. Animal Sci. 14:82.

Barnhart, C. E., J. R. Overfield and S. J. Lowry. 1959. Protein supplements for growing-finishing pigs in drylot and on alfalfa pasture. Ky. Agr. Exp. Stat. Ann. Livestock Field Day Rpt.

Conrad, J. H. and W. M. Beeson. 1957. A comparison of drylot and pasture for producing pork rapidly and economically. Purdue Univ. Agr. Exp. Stat. Mimeo A.H. 213.

Crampton, E. W. and G. C. Ashton. 1946. The effects of a vitamin B mixture, of level of protein, and of proportion of protein of animal origin in the supplements to barley and to wheat in the bacon hog ration. Sci. Agr. 26:43.

Hutchinson, H. D., A. H. Jensen, J. V. Craig, S. W. Terrill and D. E. Becker. 1955. Comparison of free-choice and complete rations on pasture and drylot. Ill. Agr. Exp. Stat. A.S. 422.

Hutchinson, H. D., A. H. Jensen, J. V. Craig, S. W. Terrill and D. E. Becker. 1956. Comparison of free-choice and complete rations on pasture and drylot. Ill. Agr. Exp. Stat. A.S. 435.

Lu, K. H., L. M. Winters, W. J. Aunan and W. E. Rempel. 1958. Estimating the percentage of lean and fat in swine carcasses. Minn. Agr. Exp. Stat. Tech. Bul. 224.

Snedecor, G. W. 1956. Statistical Methods (5th ed.). The Iowa State College Press, Ames, Iowa.

Terrill, S. W. Your hog business. 1954. Ill. Ext. Circ. 719.

Whatley, J. A. Jr., I. T. Omtvedt, J. B. Palmer and D. F. Stephens. 1959. A comparison of pasture and confinement systems for raising hogs. Okla. Agr. Exp. Stat. Misc. Pub. MP-55:8. 